\title{
Analysis of Municipal Solid Waste Generation and Composition at Administrative Building Café in Universiti Putra Malaysia: A Case Study
}

\author{
Khairul Bariyah Abd Hamid ${ }^{1 *}$, Mohd Yusoff Ishak ${ }^{1}$, Mohd Armi Abu Samah² \\ 'Faculty of Environmental Studies, Universiti Putra Malaysia, \\ 43400 UPM Serdang, Selangor, Malaysia \\ ${ }^{2}$ Kulliyyah of Sciences, International Islamic University Malaysia, \\ Jalan Sultan Ahmad Shah, Bandar Indera Mahkota, 25200 Kuantan, Pahang, Malaysia
}

Received: January 29, 2015

Accepted: March 15, 2015

\begin{abstract}
Increasing solid waste is one of the most crucial environmental problems in Malaysia. Improper management of solid waste will cause many problems. Increasing solid waste, lack of segregation from the source, and lack of knowledge and awareness about recycling have only worsened the problem. Knowledge of solid waste generation and composition is necessary for accurate decision making in the management strategy of municipal solid waste. The objectives of this study were to measure solid waste generation and analyse and compare the composition of solid waste in two different cafés at Universiti Putra Malaysia. Solid waste samples were collected every day except for Saturdays and Sundays over a three-week period and were sorted and classified into several weighed compositions such as food waste, plastic, paper, aluminium cans, glass, metal, textiles, wood, and more. Results showed that total municipal solid waste generated during three weeks of sampling at Forestry café and Park View café were $325.75 \mathrm{~kg}$, or an average of $21.72 \mathrm{~kg} /$ day, and $2979.70 \mathrm{~kg}$, or $198.65 \mathrm{~kg} /$ day, respectively. There is significant difference in data collection between the two locations. From the result, it shows that organic waste was the main component in municipal solid waste composition for both cafés, where it is $81 \%$ for Forestry Café and $96 \%$ for Park View Café, followed by the other compositions. The high organic waste indicates the necessity for frequent collection and removal, as well as having a good prospect for organic waste recycling through composting. Based on this information, a proper waste management system can be introduced to treat the solid waste more efficiently.
\end{abstract}

Keywords: municipal solid waste, waste generation, waste composition, waste revenue

\section{Introduction}

Solid waste is one of the three major environmental problems in Malaysia apart from water pollution and air pollution [1]. Rapid urbanization and industrialization have

*e-mail: khairulbariyahabdhamid@gmail.com modified the generation of solid waste in Malaysia [2], which has increased drastically where it was expected to increase from about 9.0 million tonnes in 2000 to about 10.9 million tonnes in 2010 , and finally to about 15.6 million tonnes in 2020 [3], while the national recycling rate is estimated to be only $10 \%$ [4]. 
Table 1. Types of waste and their definitions.

\begin{tabular}{|l|l|}
\hline \multicolumn{1}{|c|}{ Type of waste } & \multicolumn{1}{c|}{ Description } \\
\hline Commercial solid waste & Any solid waste generated from any commercial activity \\
\hline Construction solid waste & $\begin{array}{l}\text { Any solid waste generated from any construction or demolition activity, including improvement, preparato- } \\
\text { ry, repair, or alteration works }\end{array}$ \\
\hline Household solid waste & $\begin{array}{l}\text { Any solid waste generated by a household, and of a kind that is ordinarily generated or produced by any } \\
\text { premises when occupied as a dwelling house, and includes garden waste }\end{array}$ \\
\hline Industrial solid waste & Any solid waste generated from industrial activity \\
\hline Institutional solid waste & $\begin{array}{l}\text { Any solid waste generated by: } \\
\text { (a) any premises approved under any written law or by the state authority for use wholly or mainly for } \\
\text { religious worship or for charitable purposes } \\
\text { (b) any premises occupied by any federal or state government department, any local authority or any } \\
\text { (c) any educational premises } \\
\text { (d) any healthcare facilities including hospitals, clinics and health centres } \\
\text { (e) any premises used as public zoos, public museums, public libraries, and orphanages }\end{array}$ \\
\hline $\begin{array}{l}\text { Solid waste which may be } \\
\text { prescribed from time to time }\end{array}$ & Any solid waste generated in other countries and imported to Malaysia for processing or disposal \\
\hline Public solid waste & Any solid waste generated by public places under the supervision or control of any local authority \\
\hline
\end{tabular}

Solid waste as stated in the Solid Waste and Public Cleansing Management Act 2007 [5] can be defined as any scrap material or other unwanted surplus substance, or rejected products arising from the application of any process; or any substance required to be disposed of as being broken, worn out, contaminated, or otherwise spoiled; or any other material that according to this Act or any other written law is required by the authorities to be disposed of, but does not include scheduled wastes as prescribed under the Environmental Quality Act 1974 (Act 127) [6], sewage as defined in the Water Services Industry Act 2006 (Act 655) [7], or radioactive waste as defined in the Atomic Energy Licensing Act 1984 (Act 304) [8].

According to [5], the type of solid waste which also can be called controlled solid waste can be divided into eight categories: commercial solid waste, construction solid waste, household solid waste, industrial solid waste, institutional solid waste, imported solid waste, public solid waste, and solid waste that may be prescribed from time to time. Table 1 shows the types of waste and their definitions.

\section{Solid Waste Management}

Many cities in Southeast Asia are unable to practise good solid waste management due to lack of several matters, including institutional, financial, technical, regulatory, knowledge, and public participation [9]. Good municipal solid waste management should cover the generation of solid waste from other sources such as commercial, industrial, and institutional, as well as municipal services. In Malaysia, a method that is always used for the disposal of municipal solid waste is through land filling, and most of the sites are open dumping areas [2]. Open dumping landfill is preferable due to the cheaper cost and it is also the most common method to treat solid waste with a high percentage of organic materials [9]. Collection of waste almost covers all urban areas, but only about $66 \%$ of rural areas of Malaysia were covered [10]. Table 2 shows the percentage of waste treatment method applied in Malaysia.

\section{Waste Management Hierarchy and Recycling}

In waste management hierarchy, waste generation must be avoided or reduced from the source and waste disposal

Table 2. Waste treatment methods practiced in Malaysia.

\begin{tabular}{|l|c|c|c|}
\hline \multirow{2}{*}{ Treatment Methods } & \multicolumn{3}{|c|}{ Percentage (\%) } \\
\cline { 2 - 4 } & 2002 & 2006 & Target 2020 \\
\hline Recycling & 5.0 & 5.5 & 22.0 \\
\hline Composting & 0.0 & 1.0 & 8.0 \\
\hline Incineration & 0.0 & 0.0 & 16.8 \\
\hline Inert landfill & 0.0 & 3.2 & 9.1 \\
\hline Sanitary landfill & 5.0 & 30.9 & 44.1 \\
\hline Other disposal sites & 90.0 & 59.4 & 0.0 \\
\hline Total & 100.0 & 100.0 & 100.0 \\
\hline
\end{tabular}

Source: [11] 
Table 3. Solid waste generation in Peninsular Malaysia by states (in thousands of tonnes).

\begin{tabular}{|l|c|c|c|c|c|c|c|}
\hline \multicolumn{1}{|c|}{ State } & 1996 & 1997 & 1998 & 1999 & 2000 & $2010^{*}$ & $\begin{array}{c}\text { Average growth rate } \\
(1998-2000, \text { in } \%)\end{array}$ \\
\hline Kuala Lumpur & n.a. & n.a. & 1,058 & 1,07 & 1,082 & 1,205 & 1.14 \\
\hline Selangor & n.a. & n.a. & 1,169 & 1,204 & 1,24 & 1,617 & 3.04 \\
\hline Pahang & n.a. & n.a. & 202 & 206 & 210 & 252 & 1.98 \\
\hline Kelantan & n.a. & n.a. & 123 & 126 & 120 & 120 & -1.22 \\
\hline Terengganu & n.a. & n.a. & 119 & 122 & 125 & 157 & 2.52 \\
\hline N. Sembilan & 245 & 250 & 267 & 278 & 291 & 427 & 4.69 \\
\hline Melaka & 192 & 200 & 208 & 216 & 225 & 322 & 4.30 \\
\hline Johor & 854 & 890 & 927 & 956 & 1,005 & 1,456 & 4.49 \\
\hline Perlis & 26 & 27 & 28 & 28 & 29 & 34 & 1.79 \\
\hline Kedah & 507 & 538 & 569 & 569 & 631 & 977 & 5.49 \\
\hline Pulau Pinang & 570 & 591 & 611 & 611 & 648 & 844 & 3.03 \\
\hline Perak & 672 & 696 & 719 & 719 & 763 & 996 & 3.06 \\
\hline Total & 3,066 & 3,192 & 6,000 & 6,137 & 6,378 & 8,407 & 2.86 \\
\hline
\end{tabular}

n.a. - not available

* estimate based on the average growth rate (1998-2000) for each state except Kelantan

Source: [12]

should be the last option to dump waste. Basically, the first option, i.e., source reduction and waste prevention, is generally designed to reduce the total amount of waste being discarded and to encourage the reuse of containers and similar products. Recycling, including techniques like composting, should become the second option of waste disposal. If waste cannot be recycled, the third option for waste disposal is incineration. Finally, sanitary landfilling is recommended as the final option due to the technological complexities and costs involved [13]. Fig. 1 shows the waste hierarchy.

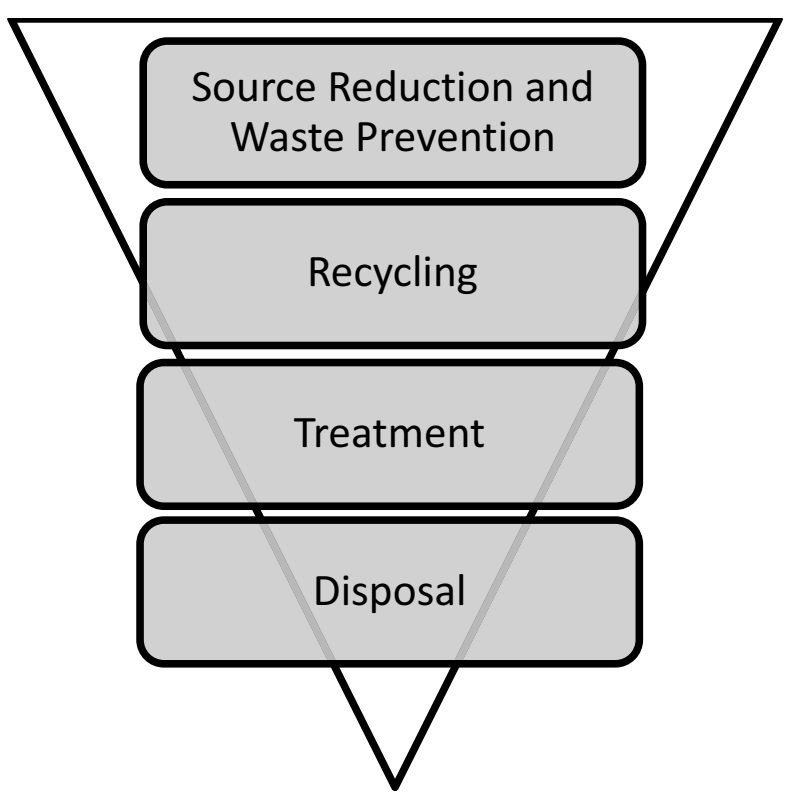

Fig. 1. The waste hierarchy.

Source: [13]
Table 4. Composition of solid waste in Malaysia in 2005.

\begin{tabular}{|c|c|}
\hline Component & Percent (\%) \\
\hline Food Waste & 45 \\
\hline Plastic & 24 \\
\hline Paper & 7 \\
\hline Steel & 6 \\
\hline Glass & 3 \\
\hline Other & 15 \\
\hline Total & 100 \\
\hline
\end{tabular}

Source: [14]

\section{Solid Waste Generation and Composition in Malaysia}

The generation of solid waste in Malaysia has increased drastically where it was expected to increase from about 9.0 million tonnes in 2000 to about 10.9 million tonnes in 2010, and finally to about 15.6 million tonnes in 2020 [3]. Table 3 shows the solid waste generation in Peninsular Malaysia by states in thousands of tonnes. Waste composition is influenced by many factors, namely level of economic development, culture, geography, energy sources, and climate. As a country that is increasingly urban and where the population is becoming wealthier, consumption of inorganic materials (plactic, paper, aluminium) is increasing while use of organic materials is decreasing [15]. 
According to RMK-9, waste in Malaysia can be divided into six compositions: food waste, plastic, paper, glass, metal, and "other." Food waste shows the highest percentage, while glass shows the lowest percentage in solid waste composition [14]. Table 4 shows the composition of solid waste in Malaysia in 2005.

\section{Technology Available for Waste Management}

A number of technologies are available in Malaysia to provide efficient solid waste management systems that are technically feasible, reliable, economically viable, environmentally sound, and socially acceptable, but the Malaysian Government has been utilizing landfilling as one of the main disposal methods for MSW.

Landfilling can be divided into two broad categories, i.e., open dumping and engineered sanitary landfill. A sanitary landfill has features consisting of liners, leachate collection and treatment, gas harvesting, and daily and final covers. There are 296 landfill/dumpsites in Malaysia and 166 are still in operation, including nine sanitary landfills [16]. More sanitary landfills are planned for opening in the future either to replace or to upgrade the current dumpsites. Landfilling solid waste is an anaerobic process. It produces landfill gases that consist of $\mathrm{CO}_{2}, \mathrm{CH}_{4}, \mathrm{H}_{2} \mathrm{~S}$, and $\mathrm{NH}_{3}$, plus other traces of gases. It can be harvested, treated, and applied for electrical generation or direct heating if not flared. Methane is known to be one of the contributors to global warming. The generation is a function of the amount of waste being deposited. Besides producing biogas, landfilling requires huge land space and also releases an unpleasant odor, and leachate requires further treatment. The sanitary landfills in Malaysia include Bukit Tagar Sanitary Landfills in Selangor and Seelong Sanitary Landfill in Johor.

Another technology available for solid waste treatment is incineration. The ignition of solid waste allows a huge volume reduction for both solid waste and hazardous wastes. There are four incinerators owned by the government and one operated by a private company, named Recycle Energy Sdn. Bhd. at Semenyih, with a capacity for 1,000 metric tonnes per day. The other four incinerators are located in Pulau Pangkor, Pulau Langkawi, Pulau Tioman, and Cameron Highlands. Even though incineration does not produce greenhouse gases (GHG), it produces harmful gases, particles, and ash. Incinerators are equipped with scrubbers and other prevention technologies to remove those potential pollutants.

Composting of municipal solid waste is another approach used by some at community or individual levels. Some utilize earthworms to decompose the solid waste especially food waste - in a method referred to as vermincomposting. Some private companies utilize anaerobic digesters to treat their organic waste on a small scale. According to Tarmudi [12], composting is a process that involves the biological decomposition of the organic matter under controlled operation to produce a humus-like stable product. It involves the aerobic digestion of the biodegradable fraction of MSW, such as paper and cardboard, and food and garden waste.
Recycling is also one of the approaches to manage solid waste. Recycling refers to the collection and separation of waste and its transformation and remanufacturing into usable and marketable materials [12]. In Malaysia, recycling programs were first launched in 1993. Unfortunately, only some people practice it, even though Malaysians' generally hold recycling in high regard. The recycling program was relaunched by the Ministry of Human Wellbeing, Housing and Local Government in December 2000, and the government declared 11 November as National Recycling Day [2]. According to Budhiarta [17], if compared before and after the recycling program was launched, the generation of waste produced every day does not show any reduction and is still the same.

\section{Problem Statement}

In Malaysia, solid waste is a major environmental problem. Increasing waste quantity can cause many problems because improper practices with respect to waste management leads to pollution, resource degradation, and health problems for humans and animals. Besides, no segregation from the source also has worsened the problem. Most of Malaysian waste is mixed waste, which means there is organic and inorganic waste. Organic waste can be used as composting materials while inorganic waste can be used and sent for recovery and recycling. Lack of awareness and knowledge to do recycling among the Malaysian community as well as being ignorant also causes the problem to become more severe. Many people are also unaware of the individual actions they can take to help curb the problem. This study will show about solid waste generation and composition at two different cafés at UPM. From waste generation and composition, a proper waste management system can be introduced to treat solid waste more efficiently.

Objectives of the study:

- To study waste generation at two different cafés at UPM (Park View Café and Forestry Café)

- To determine and statistically analyse solid waste composition at two different UPM cafés

- To estimate waste revenue at both cafés in UPM for a year

\section{Methodology}

\section{Solid Waste Study}

The study on solid waste generation and composition at two different cafés in UPM consisted of three main stages:

1) weighing the waste

2) recording the data

3) analysing the data

The data was obtained by direct methods, meaning direct weighing of the solid waste collected from the café where it was generated throughout the day. The data collection was conducted for 3 weeks, continuously except for Saturdays and Sundays. The weighing process was conducted every day after the café was closed. Garbage bags 


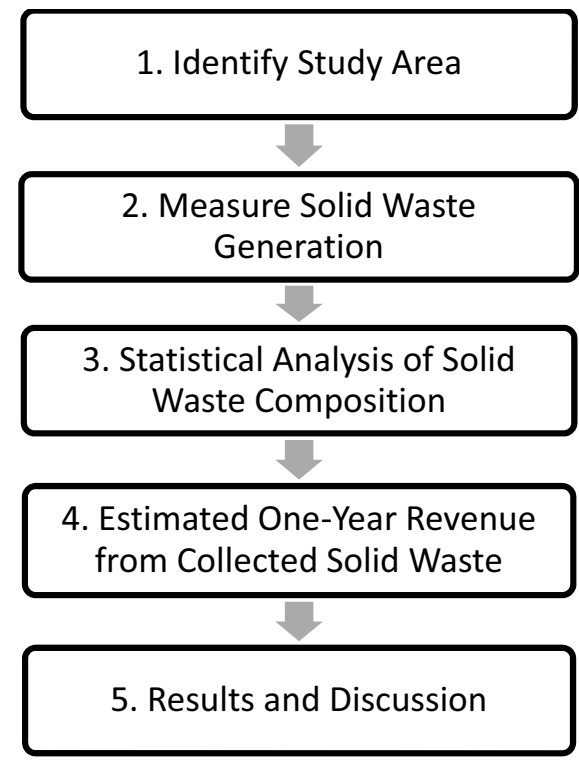

Fig. 2. Research methodology framework.

were provided to each café during the period of the sampling. The solid waste was separated into two categories, which were wet waste and dry waste by the cafés owner. Wet waste composition contains mostly food waste and dry waste composition contains mostly plastic, paper, cans, and other materials. Then the solid waste is segregated by its type and the weighing process was conducted using a $50 \mathrm{~kg}$ scale. Fig. 2 shows the research methodology framework for this study and Appendix 1 and Appendix 2 shows the flow of sampling process.

\section{Study Area}

The study was carried out within Universiti Putra Malaysia (UPM). The study areas were Park View Café and Forestry Café - both chosen based on their locations near the staff and student centre. The Park View is located near the UPM main administration building and the Office of Development and Asset Management. It is open from 7:30 a.m. to $6: 30$ p.m., thus serving as an area where the staff, students, and public can go before continuing their business. The Forestry Café, is located in-between the Faculty of Forestry, the Lecture Hall, the Co-curicullum Centre, the Student Off-Campus Centre, and the Bus Centre. It is open 8 a.m. to $4: 30$ p.m., thus becoming a place where people can stop before continuing their work elsewhere. Fig. 3 shows the map of study area/sampling site.

\section{Data Analysis}

For data analysis, the data from solid waste generation and composition that had been collected and weighed was analysed using Excel. The data showed the relationship between quantities generated over time. The data from both sites (Park View and Forestry) was compared and analysed, also the waste revenue for both was estimated.
Table 5. Total daily waste generated $(\mathrm{kg})$ at the Forestry Café.

\begin{tabular}{|c|c|}
\hline Day & Total Waste Generated (kg) \\
\hline 1 & 14.55 \\
\hline 2 & 17.60 \\
\hline 3 & 14.00 \\
\hline 4 & 23.00 \\
\hline 5 & 17.60 \\
\hline 6 & 26.70 \\
\hline 7 & 23.40 \\
\hline 8 & 29.15 \\
\hline 9 & 20.40 \\
\hline 10 & 18.00 \\
\hline 11 & 29.15 \\
\hline 12 & 23.90 \\
\hline 13 & 20.30 \\
\hline 14 & 23.90 \\
\hline 15 & 24.10 \\
\hline Total & 325.75 \\
\hline
\end{tabular}

\section{Results}

\section{Solid Waste Generation and Composition at Forestry Café}

Forestry Café comprises two small buildings located not far from each other. One building is for the dining area and the other is where they sell food and drink. Most of the food sold is prepared at a different location before it is brought to the café. There is no cooking activity done there except for cooking simple dishes such as frying eggs. The Forestry does not practice waste separation or resource recovery. All solid waste is disposed of in one garbage bin.

Table 5 shows total solid waste generated at the Forestry during three weeks of sampling except for Saturdays and Sundays. The total of solid waste generated is $325.75 \mathrm{~kg}$. Thus, average solid waste generated for a day is $21.72 \mathrm{~kg}$. Based on Fig. 4, days 8 and 11 recorded the highest solid waste generated: $29.15 \mathrm{~kg}$. Meanwhile, day 3 recorded the lowest solid waste generated at $14.00 \mathrm{~kg}$.

Table 6 shows that organic waste dominates solid waste generation during three weeks of sampling except for Saturdays and Sundays by producing about $263.30 \mathrm{~kg}$ (or an average of $17.55 \mathrm{~kg}$ per day), while glass only produced about $2.05 \mathrm{~kg}$ (or an average of $0.14 \mathrm{~kg}$ per day). The highest value recorded is $25.30 \mathrm{~kg}$ for organic waste and the lowest is $0.10 \mathrm{~kg}$ for paper. There are some unrecorded values for glass, which indicates that there is no glass waste disposed on that day. 
Table 6. Statistical analysis results of solid waste at the Forestry Café.

\begin{tabular}{|l|c|c|c|c|c|c|}
\hline \multirow{2}{*}{ Parameters } & \multicolumn{6}{|c|}{ Waste Composition (kg) } \\
\cline { 2 - 7 } & Organic Waste & Paper & Plastic & Metal & Glass & Others \\
\hline Sum & 263.30 & 7.90 & 25.20 & 16.30 & 2.05 & 11.00 \\
\hline Mean & 17.55 & 0.53 & 1.68 & 1.09 & 0.14 & 0.73 \\
\hline SD & 4.31 & 0.54 & 0.50 & 0.36 & 0.21 & 0.44 \\
\hline Variance & 18.54 & 0.29 & 0.25 & 0.13 & 0.04 & 0.19 \\
\hline Minimum & 10.20 & 0.10 & 0.80 & 0.70 & 0.00 & 0.30 \\
\hline Maximum & 25.30 & 2.10 & 2.50 & 1.90 & 0.60 & 1.70 \\
\hline
\end{tabular}

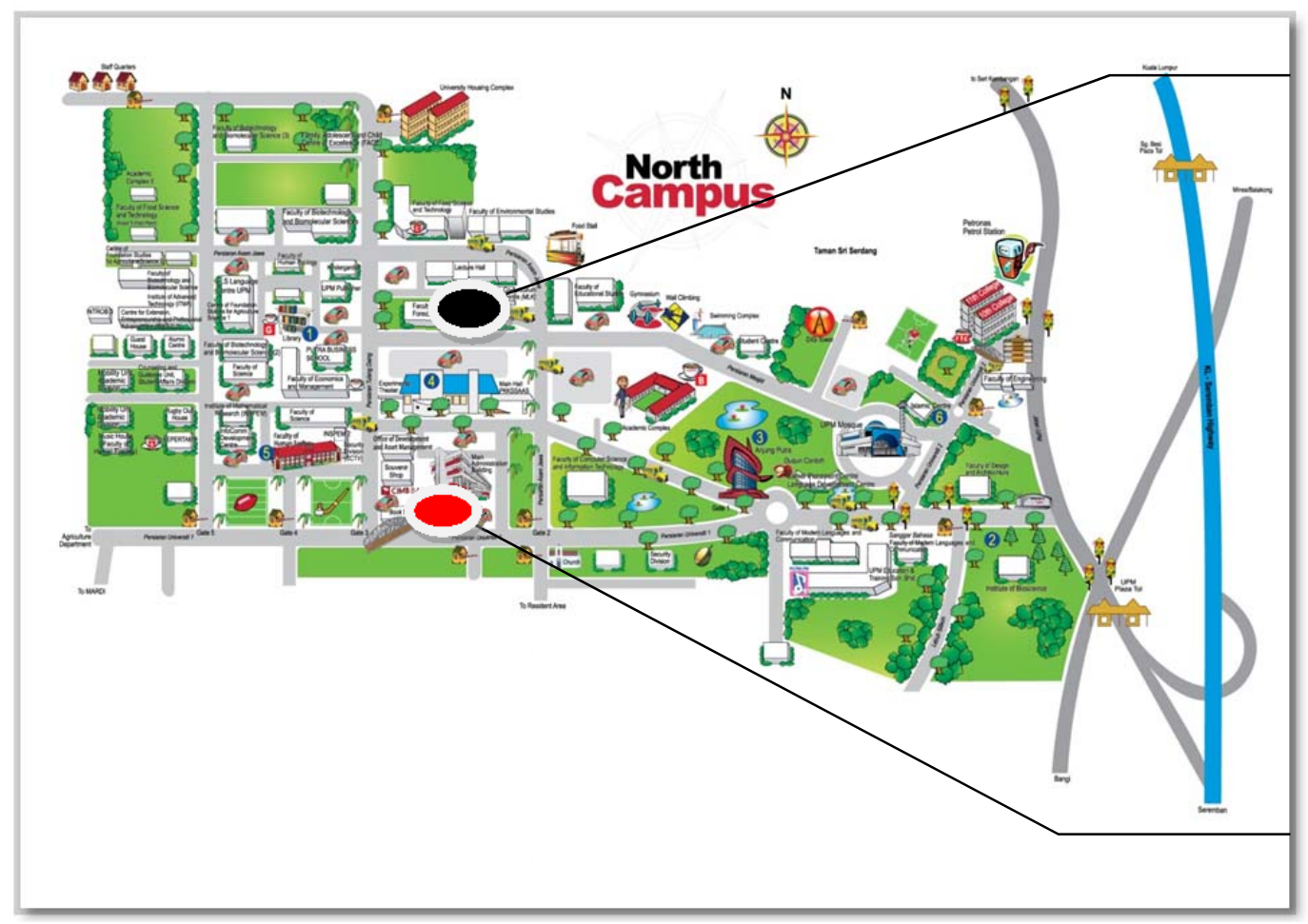

Forestry Café

Fig. 3. Map of UPM North Campus.

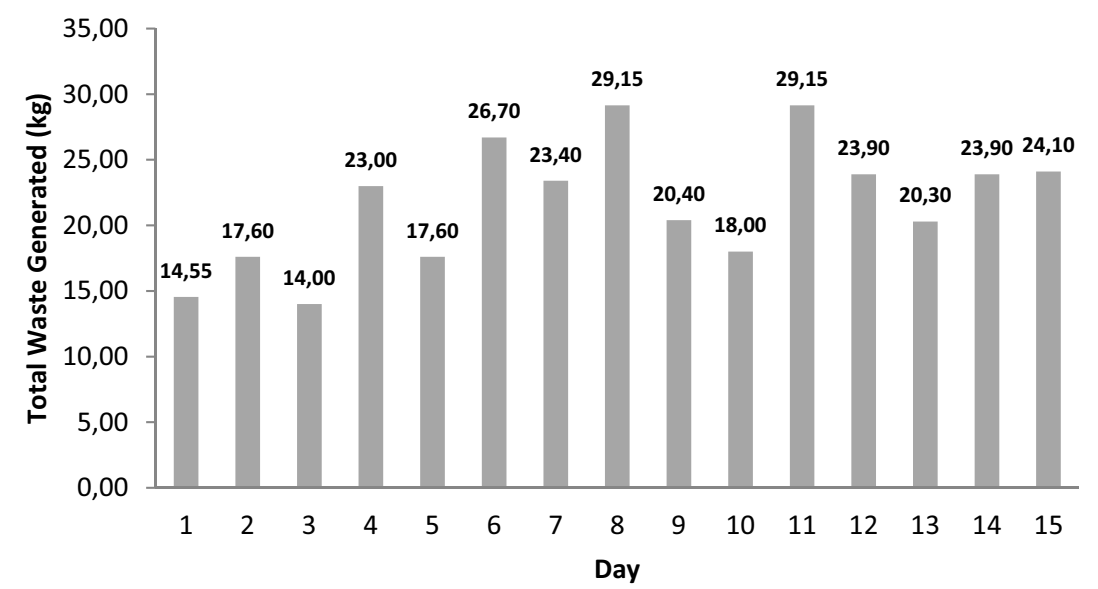

Fig. 4. Graph of waste generated $v s$. day at Forestry Café. 


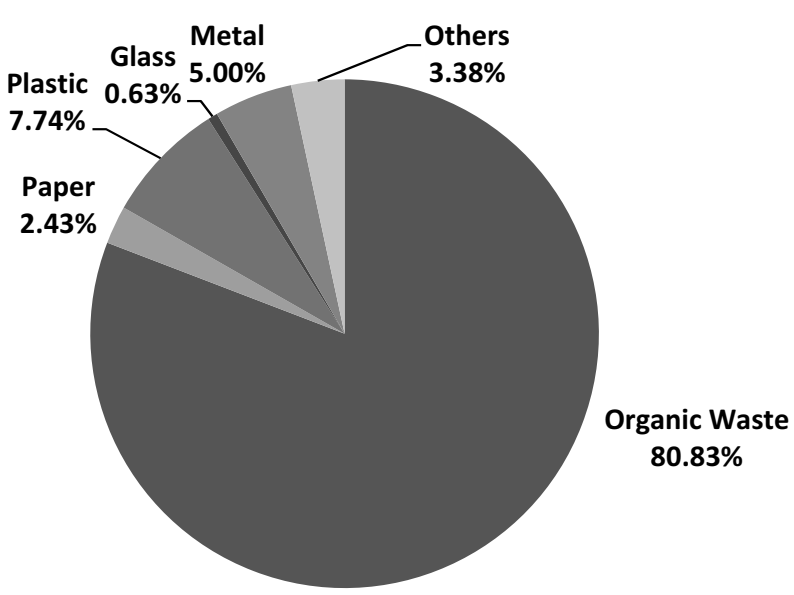

Fig. 5. Percentage of solid waste composition at Forestry Café.

Waste composition at Forestry Café consists of approximately $81 \%$ organic waste followed by $8 \%$ plastic, $5 \%$ metal, $3 \%$ others, $2 \%$ paper, and $1 \%$ glass. Fig. 5 illustrates the percentage of solid waste composition at Forestry Café. As for organic waste, the majority of the waste is food waste and banana leaves (used as nasi lemak wrapper). For plastic waste it consists of drinks packaging, drinking straws, fruit wrappers, bottles, and raffia ropes. Paper waste consists of egg cartons, mineral bottle boxes, and a few cigarette boxes and tissues. Glass is rarely disposed of, only once or twice a week. For metals, most of it is aluminium cans/tins. As for the "others," the majority of these wastes are polystyrene but sometimes there is also wood. During peak times, because of insufficient plates, customers had to use polystyrene plates. This is why the composition of polystyrene disposal is high.

\section{Solid Waste Generation and Composition at Park View Café}

Park View Café consists of two parts: an indoor area and an outdoor area. All of the sales are conducted at the indoor area. The outdoor area is for dining purposes only.
Table 7. Total waste generated $(\mathrm{kg})$ by day at Park View Café.

\begin{tabular}{|c|c|}
\hline Day & Total Waste Generated $(\mathrm{kg})$ \\
\hline 1 & 212.20 \\
\hline 2 & 196.90 \\
\hline 3 & 223.60 \\
\hline 4 & 183.10 \\
\hline 5 & 175.90 \\
\hline 6 & 205.10 \\
\hline 7 & 231.00 \\
\hline 8 & 199.30 \\
\hline 9 & 209.00 \\
\hline 10 & 185.10 \\
\hline 11 & 186.60 \\
\hline 12 & 185.70 \\
\hline 13 & 204.60 \\
\hline 14 & 194.10 \\
\hline 15 & 187.50 \\
\hline Total & 2979.70 \\
\hline
\end{tabular}

Observations during sampling showed that all customers who dine-in at the café must clean their own tables after they finish their meals. All the leftover food is required to be thrown in a bin labelled "food waste," and the dishes must be placed in respective containers. For plastics, papers, and metals, the café practices resource recovery. All recyclable materials are collected and sold.

Table 7 shows total solid waste generated at Park View during three weeks of sampling, except for Saturdays and Sundays. The total of solid waste generated at Park View is $2979.70 \mathrm{~kg}$. Thus, solid waste generated for each day is $198.65 \mathrm{~kg}$. Based on Fig. 6, day 7 recorded the highest solid waste generated $(231.00 \mathrm{~kg})$, while day 5 recorded the lowest solid waste generated $(175.90 \mathrm{~kg})$.

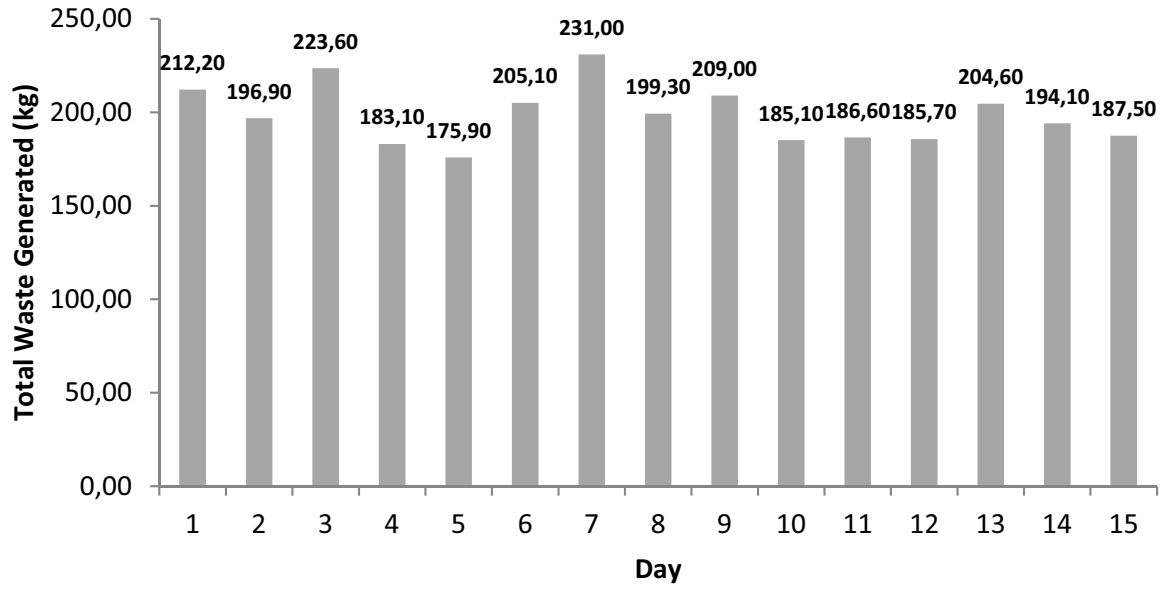

Fig. 6. Graph of waste generated vs. day at Park View Café. 
Table 8. Statistical analysis results of waste generation at Park View Café.

\begin{tabular}{|l|c|c|c|c|c|c|}
\hline \multirow{2}{*}{ Parameters } & \multicolumn{6}{|c|}{ Waste Composition (kg) } \\
\cline { 2 - 7 } & Organic Waste & Paper & Plastic & Metal & Glass & Others \\
\hline Sum & $2,846.60$ & 26.40 & 41.40 & 50.20 & 10.20 & 4.70 \\
\hline Mean & 189.77 & 1.76 & 2.76 & 3.35 & 0.68 & 0.31 \\
\hline SD & 15.17 & 0.43 & 0.64 & 0.36 & 0.09 & 0.19 \\
\hline Variance & 230.17 & 0.18 & 0.41 & 0.13 & 0.01 & 0.04 \\
\hline Minimum & 168.60 & 1.00 & 2.20 & 2.70 & 0.50 & 0.10 \\
\hline Maximum & 221.50 & 2.90 & 4.20 & 4.10 & 0.80 & 0.70 \\
\hline
\end{tabular}

Table 8 shows that organic waste dominates the solid waste generated during three weeks of sampling (except for Saturday and Sunday) by producing about $2846.60 \mathrm{~kg}$, or $189.77 \mathrm{~kg}$ per day, while others only produced about $4.70 \mathrm{~kg}$ or $0.31 \mathrm{~kg}$ per day. The highest value recorded is $221.50 \mathrm{~kg}$ for organic waste and the lowest value recorded is $0.10 \mathrm{~kg}$ for "others."

For the solid waste composition at Park View Café, organic waste shows the highest percentage, comprising $96 \%$. Fig. 7 illustrates the percentage of solid waste composition at Park View Café. Organic waste at Park View Café consists mainly of processed kitchen waste such as meat and vegetable and food waste. All cooking activity is done at the café. So the raw materials such as meat and vegetables are processed there. Besides that, most of the customers will dine-in at the café because of the huge dining area. So the percentage of food waste is rather high. For paper and others, the composition is less than $1 \%$. This is because the customers that dine-in at the Café use the plates provided by the Café. Therefore, there is less consumption of polystyrene.

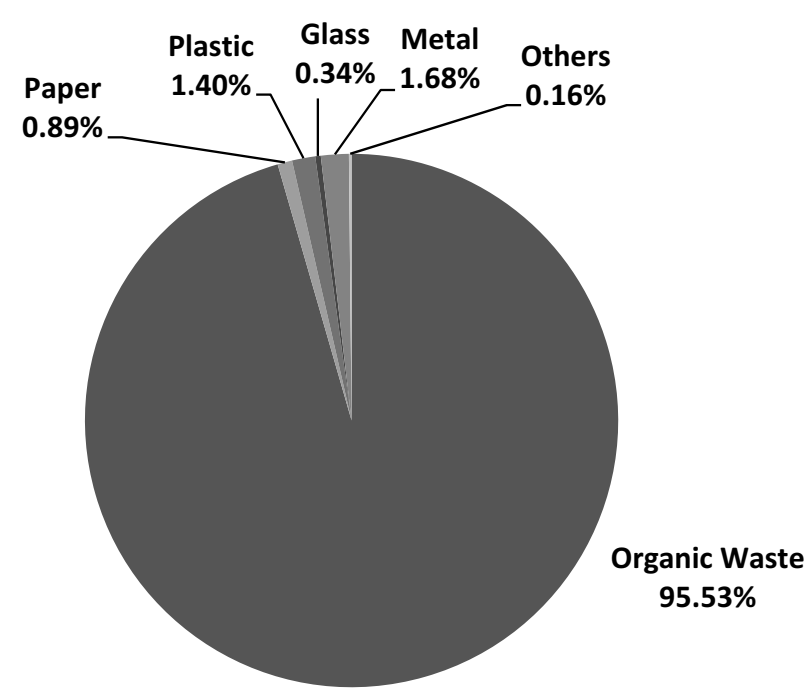

Fig. 7. Percentage of solid waste composition at Park View Café.
Table 9. One-sample Kolmogorov-Smirnov test.

\begin{tabular}{|l|c|c|}
\hline & Forestry Café & Park View Café \\
\hline $\mathrm{N}$ & 15 & 15 \\
\hline Mean & 21.72 & 198.65 \\
\hline $\mathrm{SD}$ & 4.76 & 15.68 \\
\hline Asymp. Sig. (2-tailed) & 0.93 & 0.83 \\
\hline
\end{tabular}

Table 10. Statistical analysis results of solid waste generated $(\mathrm{kg})$.

\begin{tabular}{|l|c|c|}
\hline \multirow{2}{*}{ Parameters } & \multicolumn{2}{|c|}{ Solid Waste Generated (kg) } \\
\cline { 2 - 3 } & Forestry Café & Park View Café \\
\hline Sum & 325.750 & 2979.700 \\
\hline Mean & 21.717 & 198.647 \\
\hline SD & 4.761 & 15.678 \\
\hline Variance & 22.671 & 245.796 \\
\hline Minimum & 14.000 & 175.900 \\
\hline Maximum & 29.150 & 231.000 \\
\hline
\end{tabular}

\section{Statistical Analysis between Forestry Café and Park View Café}

A one-sample Kolmogorov-Smirnov test was done to check the normality of the data collected. Large significant values $(>0.05)$ indicate that the observed distribution corresponds to the theoretical distribution. Results (Table 9) show that the test distribution is normal. The $\mathrm{p}$ values for Forestry and Park View cafés are 0.93 and 0.83 , respectively, which are more than 0.05 .

Statistical analysis results for total solid waste generated $(\mathrm{kg})$ for both cafés is summarised in Table 10. Using data from both cafés, one-sample t-test is done to know whether the differences in waste generated at both locations are significant. Based on the results (Table 11), there is significant 
Table 11. T-test.

\begin{tabular}{|l|c|c|c|c|c|c|}
\hline \multirow{2}{*}{ Location } & T & Df & Sig. (2-tailed) & \multirow{2}{*}{ Mean Difference } & \multicolumn{2}{c|}{ 95\% Confidence Interval of the Difference } \\
\cline { 5 - 7 } & & & & & Lower & Upper \\
\hline Forestry Café & 17.67 & 14 & 0.00 & 21.72 & 19.18 & 24.35 \\
\hline Park View Café & 49.07 & 14 & 0.00 & 198.65 & 189.96 & 207.33 \\
\hline
\end{tabular}

A)

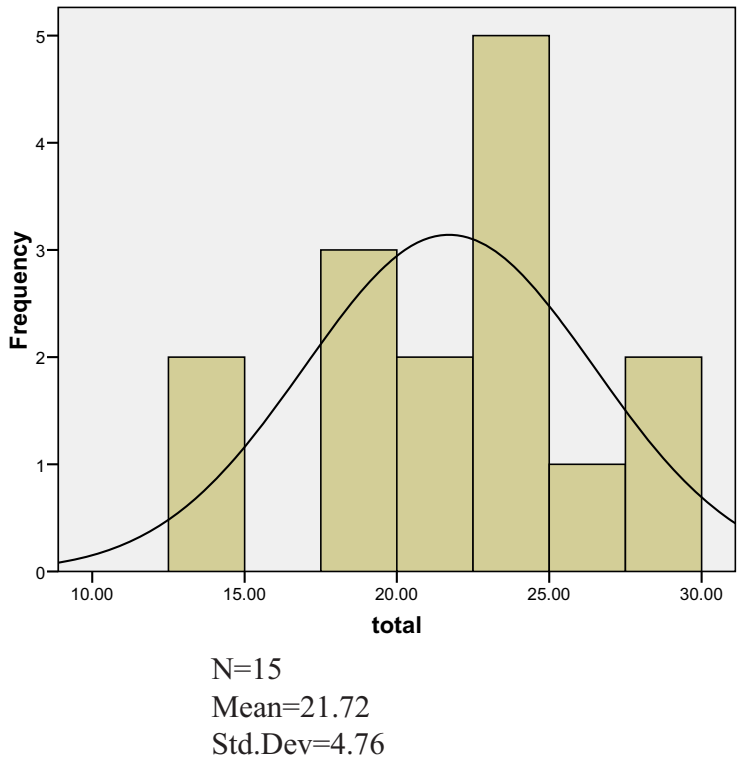

B)

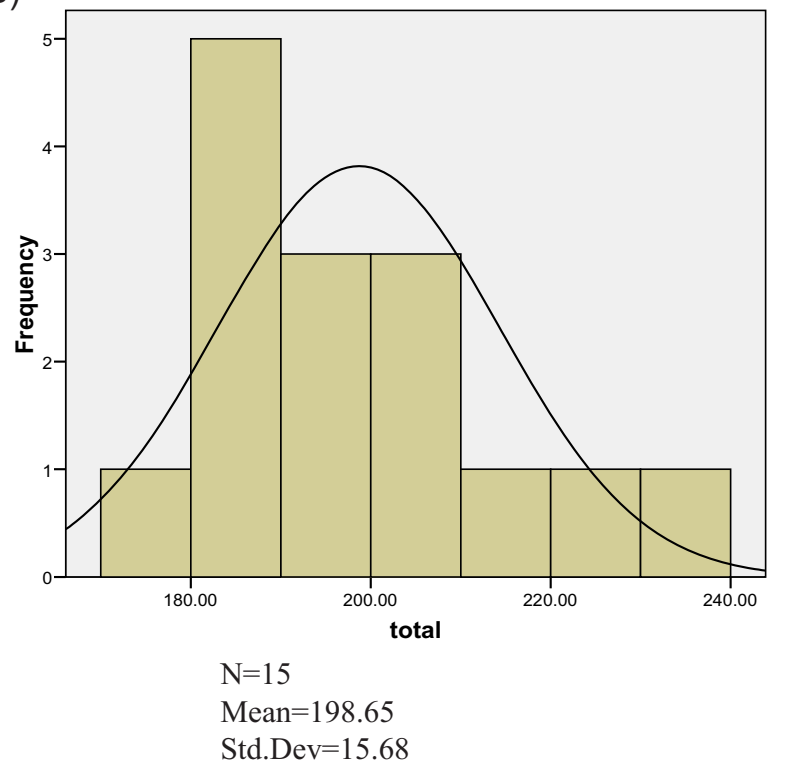

Fig. 8. Frequency distribution of total waste generated (kg) at (A) Forestry Café and (B) Park View Café.

difference between the two locations as $\mathrm{p}=0.00$ at a significance level of $\alpha=0.05$. The mean of total solid waste generated at Forestry and Park View was $21.72 \mathrm{~kg}$ and 198.65, respectively. The significant difference is because more customers visit Park View compared to Forestry, which indicates why there is higher waste generated at Park View daily.

Fig. 8 shows a histogram with normal curve for total waste generation at Forestry and Park View. The histogram clearly shows that the majority of the total waste generated was $>21.72 \mathrm{~kg}$ at Forestry and $<198.65 \mathrm{~kg}$ at Park View.

Based on the study area, Park View has a larger area compared to Forestry. Indirectly, Park View produces more solid waste since they operate at a larger scale. Fig. 9 shows higher value for organic waste, paper, plastic, glass, and metal except for "others," where Forestry produced more than Park View. As mentioned before, Forestry produces a higher amount of polystyrene.

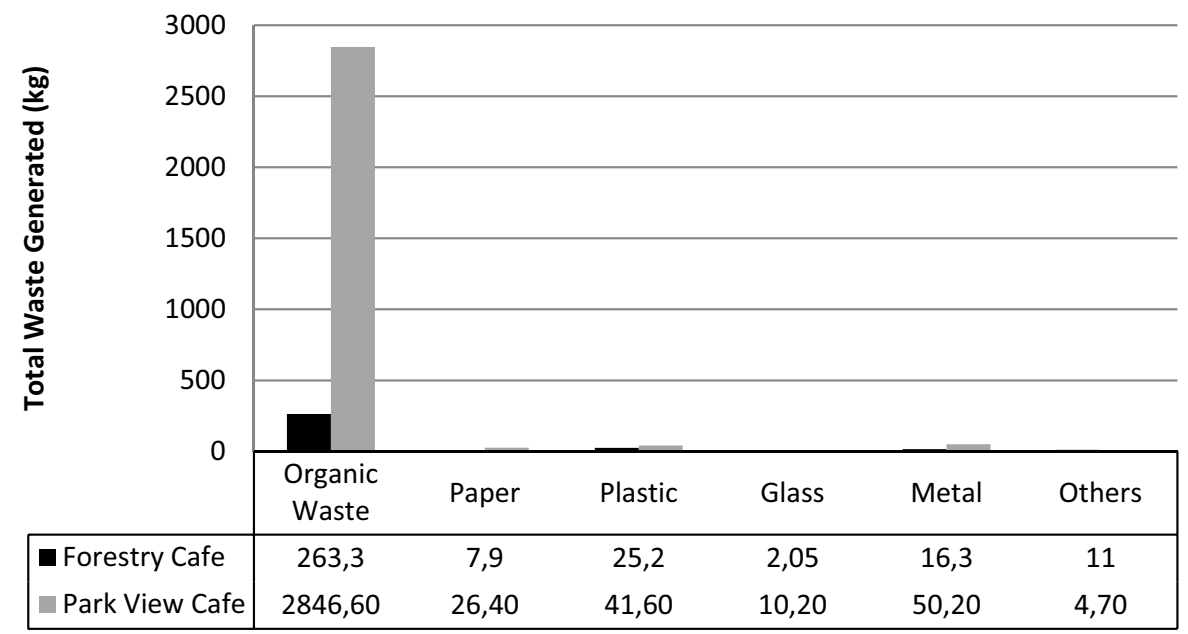

Fig. 9. Total waste generated $(\mathrm{kg})$ by composition. 


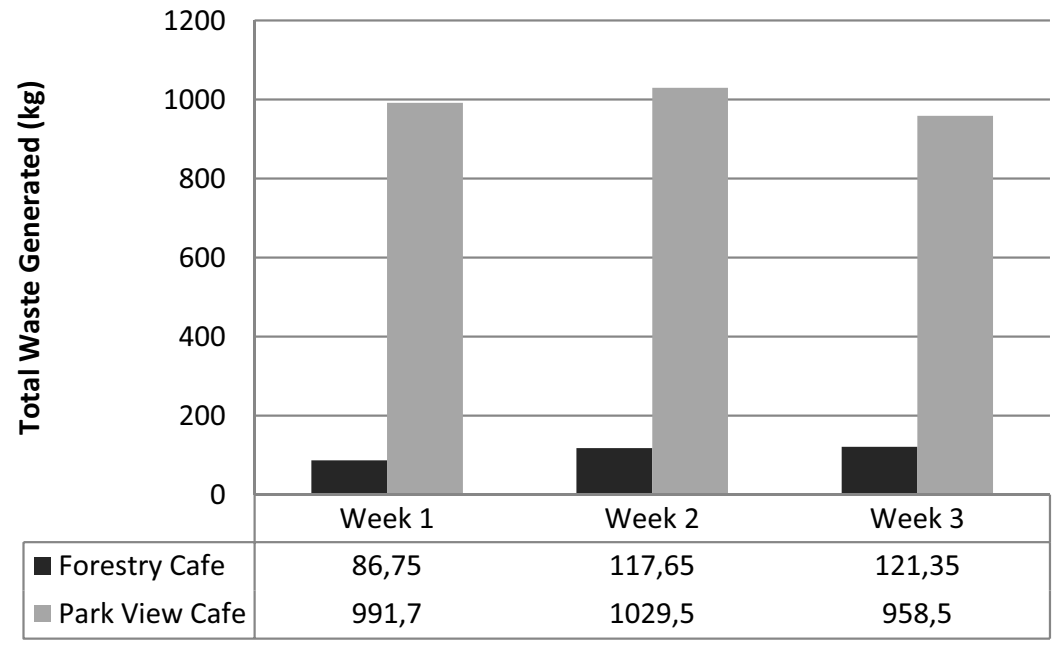

Fig. 10. Total waste generated by week.

During the three weeks of sampling, based on Fig. 10 Forestry showed an increasing amount of solid waste generated week by week, but Park View showed fluctuating results. For Park View, their amount of solid waste generated daily depends on the main menu of the day since they have different menus for each day. Both of the cafés generated higher waste during the second week because it was convocation week in Universiti Putra Malaysia, so there were more visitors at both cafés during the whole week.

Table 12. List price for recycled materials.

\begin{tabular}{|l|c|}
\hline \multicolumn{1}{|c|}{ Material } & Price (RM/kg) \\
\hline Newspaper & 0.24 \\
\hline Black and White Paper & 0.36 \\
\hline Box & 0.22 \\
\hline Magazine & 0.22 \\
\hline Mixed Paper & 0.18 \\
\hline Tetra Pack & 0.50 \\
\hline Can/Metal & 0.40 \\
\hline CD/VCD Casing & 0.20 \\
\hline Aluminium can/Stainless Steel & 3.00 \\
\hline Car's Battery & 1.00 \\
\hline Plastic & 0.40 \\
\hline Glass & - \\
\hline Computer & 4.00 per unit \\
\hline Used cooking oil & 0.80 \\
\hline CD/VCD & 0.60 \\
\hline
\end{tabular}

The price for recycled materials above are varies according to the current market price.

Source: [22]
Table 13. Estimated revenues received from collected recyclable materials for Forestry Café.

\begin{tabular}{|l|c|c|c|}
\hline Type & $\begin{array}{c}\text { Total Amount } \\
\text { Collected } \\
(\mathrm{kg})\end{array}$ & $\begin{array}{c}\text { Unit } \\
\text { Price } \\
(\mathrm{RM} / \mathrm{kg})\end{array}$ & $\begin{array}{c}\text { Estimated } \\
\text { Revenue } \\
(\mathrm{RM})\end{array}$ \\
\hline Paper (Box) & 7.90 & 0.22 & 1.74 \\
\hline Plastic & 25.20 & 0.40 & 10.08 \\
\hline Metal (Can) & 16.30 & 0.40 & 6.52 \\
\hline \multicolumn{3}{|l|}{ Total } & 18.34 \\
\hline
\end{tabular}

\section{Waste Revenue}

From the solid waste generated we can also estimate the waste revenue for each café. The list price for recycled materials varies according to the current market price. Table 12 shows the price for recycled materials in Malaysia provided by the Ministry of Human Wellbeing, Housing and Local Government's (KPKT) website.

From Table 13 the estimation of waste revenue for three weeks (15 days) of sampling at Forestry Café is RM18.34. So the average revenue they can get per day is RM1.22. In a month, Forestry Café can get approximately RM36.68. Thus, it can save about RM440.16 per year. Based on the revenue recorded, plastic gives the highest price (RM10.08) and paper gives the lowest price (RM1.74).

From Table 14, estimation for waste revenue for three weeks (15 days) of sampling at Park View Café is RM66.58. So the average revenue they can get per day is RM4.44. In a month, Park View Café can get approximately RM133.20. Thus, it can save about RM1598.40 per year. Based on the revenue recorded, aluminium gives the highest price (RM26.10) and mixed paper gives the lowest price (RM0.59). 
Table 14. Estimated revenues received from collected recyclable materials for Park View Café.

\begin{tabular}{|l|c|c|c|}
\hline \multicolumn{1}{|c|}{ Type } & $\begin{array}{c}\text { Total Amount } \\
\text { Collected } \\
(\mathrm{kg})\end{array}$ & $\begin{array}{c}\text { Unit } \\
\text { Price } \\
(\mathrm{RM} / \mathrm{kg})\end{array}$ & $\begin{array}{c}\text { Estimated } \\
\text { Revenue } \\
(\mathrm{RM})\end{array}$ \\
\hline Paper (Box) & 17.50 & 0.22 & 3.85 \\
\hline Paper (Mixed paper) & 3.30 & 0.18 & 0.59 \\
\hline Paper (Tetra pack) & 5.60 & 0.50 & 2.80 \\
\hline Plastic & 41.60 & 0.40 & 16.64 \\
\hline Metal (Can) & 41.50 & 0.40 & 16.60 \\
\hline Metal (Aluminium) & 8.70 & 3.00 & 26.10 \\
\hline Total & & & 66.58 \\
\hline
\end{tabular}

\section{Discussion}

Based on the results, food waste dominates solid waste stream at both cafés. As we know, food waste contains mainly organic matter. Burying organic waste in a landfill is a big problem because it breaks down and creates harmful greenhouse gases like methane, which damages the Earth's atmosphere if the waste is not treated properly. There are many benefits that we can get by recycling organic waste. Besides protecting the environment, we can also save money.

Responsible parties at both cafés must provide separate bins for waste disposal. One for organic waste like food waste and another for inorganic waste like paper, plastic, glass, metal, and other. Using the collected food waste, composting can be practiced. Food waste can be recycled in several ways, including in-vessel composting and anaerobic digestion. In-vessel composting involves mixing food waste with garden waste, shredding it, and then composting it in an enclosed system for around 2-4 weeks. Meanwhile, anaerobic digestion uses microorganisms to break down food waste, animal manure, slurries, and energy crops in the absence of oxygen, inside an enclosed system. For inorganic waste, it can be sent to recycle. Apart from waste minimisation, they also can gain money.

For Park View, they already segregate their waste. For food waste, they directly dispose of the waste in a garbage bin. For inorganic waste like paper, plastic, and metal, they send it for recycling. For Forestry they do not practice waste segregation. All their wastes are directly disposed of into one garbage bin. Then, after the café is closed, the waste is collected and disposed of at a larger garbage bin.

Much research has been conducted regarding waste generation and composition in Malaysia. Most of them show that organic waste dominates the waste stream in Malaysia, for example a municipal solid waste composition study at Universiti Kebangsaan Malaysia by Tiew [18] con- cerning a particular type of municipal solid waste which is "tropical campus waste." The primary aim is to develop a representative estimation of the composition of the university's municipal solid waste stream. The study was conducted at the main campus. Twelve samples were taken over a four-week period. The daily waste was separated into organics $(55 \%)$, plastics $(30 \%)$, paper $(11 \%)$, glass $(1 \%)$, and metal $(2 \%)$, plus rubber, leather, and wood $(1 \%)$. Organic waste showed the highest percentage while glass, rubber, and leather and wood showed the lowest percentage.

Other research that has been done is household solid waste characteristics and management in a low-cost apartment in Petaling Jaya, Selangor by Yatim [19]. One of the objectives of the study was to characterise the generation of waste. Three-hundred and sixty samples were collected over a six-week period from 60 households. Organic waste $(43.5 \%)$, plastic $(25.2 \%)$, and paper $(22.7 \%)$ showed the leading percentages.

The latest research that has been conducted is real data composition of municipal solid waste generated in Balakong, Selangor, Malaysia by Samah [20], whose aim was to study solid waste composition in Balakong, Selangor. The area covered eight residential areas, two industrial areas, and one hypermarket. The sampling was conducted for one month on a daily basis. Organic waste showed the highest percentage $(48.07 \%)$, followed by paper $(29.53 \%)$, plastic $(16.69 \%)$, others $(2.65 \%)$, glass (1.90\%), and metal (1.16\%).

Other research that has been done is household solid waste composition in Balakong City, Malaysia: trend and management by Samah et al. [21]. The paper focuses on the trend and management of the household solid waste composition generated. A survey was conducted at eight housing areas in a one-month period on a daily basis. Organic wastes $(69.4 \%)$ record the highest percentage, followed by plastic $(10.3 \%)$, paper $(9.3 \%)$, other waste $(5.4 \%)$, and glass $(3.2 \%)$. Metal $(2.4 \%)$ shows the lowest percentage.

\section{Conclusion}

This paper provides an opportunity to study solid waste generation and composition at Administrative Building Cafés, Universiti Putra Malaysia. Results clearly show that organic waste dominates the solid waste composition at Forestry Café and Park View Café at approximately $81 \%$ and $96 \%$, respectively. The high organic waste indicates the necessity for frequent collection and removal, thus can be efficient for generating added-value products (e.g. compost/manure, biogas, etc.). So, UPM should develop a policy that makes it compulsory for cafés in UPM to separate their recyclable wastes. A proper way to dispose of food waste (organic waste) can be introduced. UPM should propose to buy its own composting machine to produce organic fertiliser. Other waste such as paper, plastic, metal, and other composition that has value can be sent to a recycling centre. 
Appendix 1. Sampling method at Forestry Café.

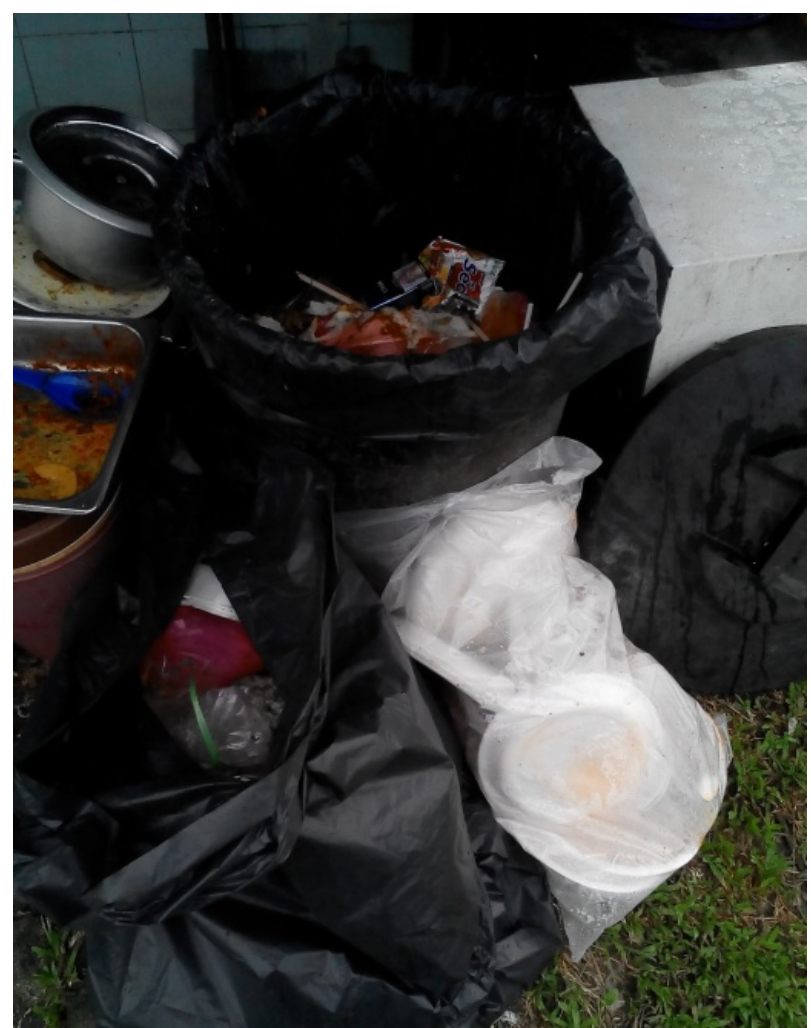

(A) Solid waste generated in a day.

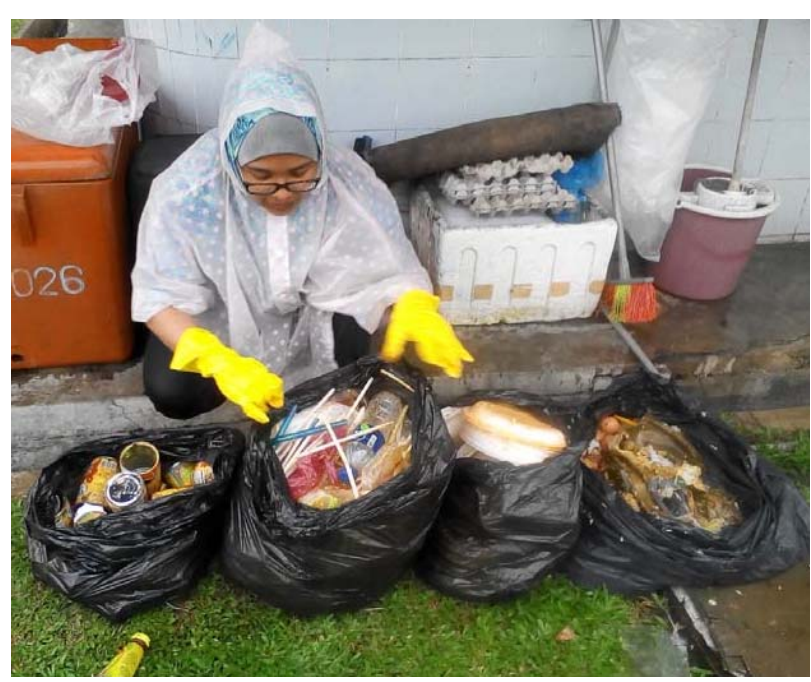

(B) Segregation by its composition based on Malaysian standards.

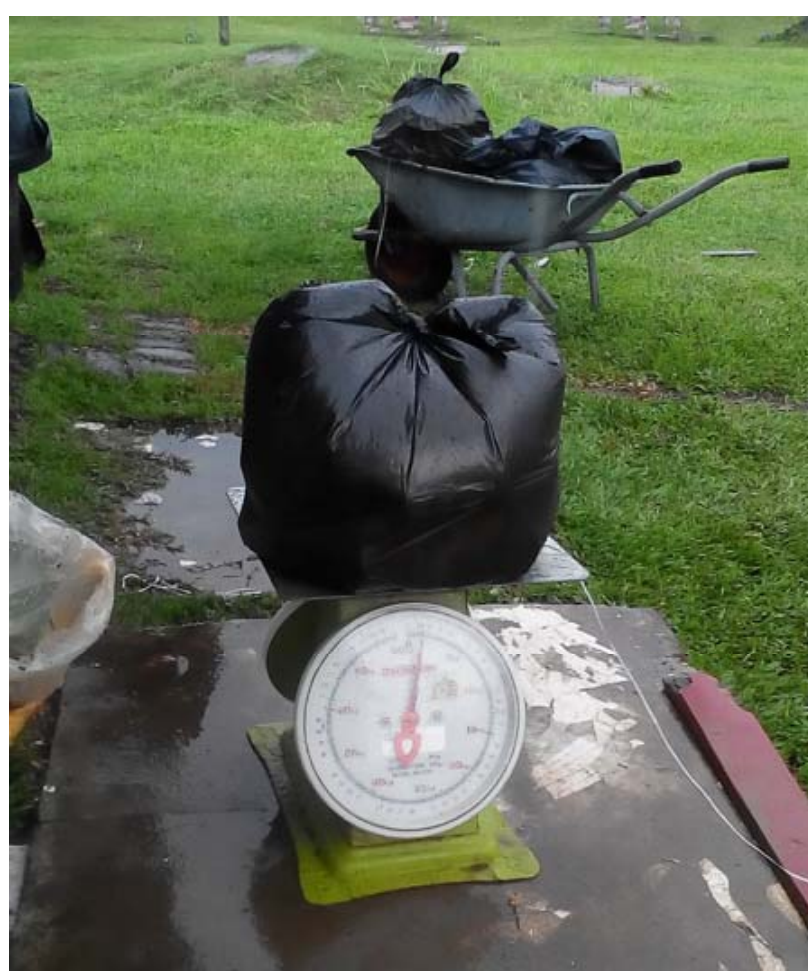

(D) Weighing process.

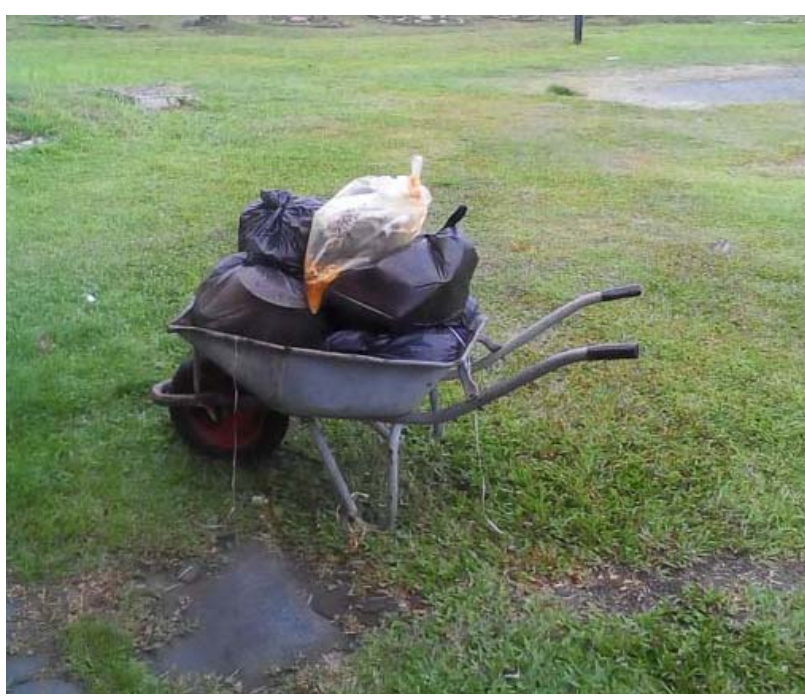

(E) Sampling process completed.

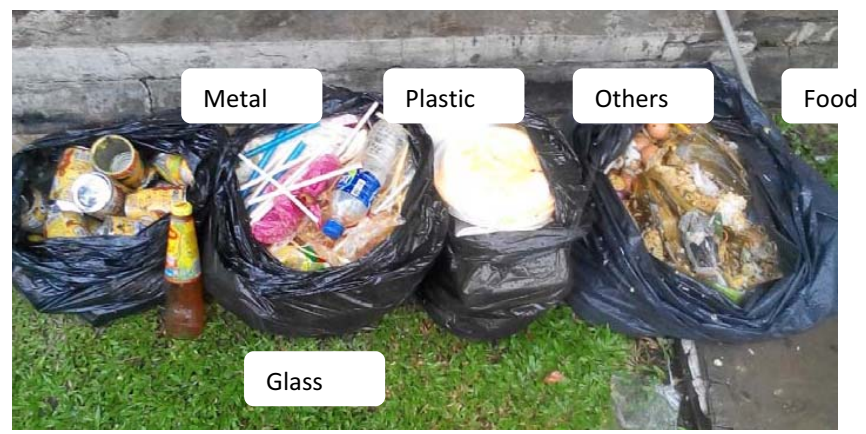

(C) Complete waste segregation. 
Appendix 2. Sampling method at Park View Café.

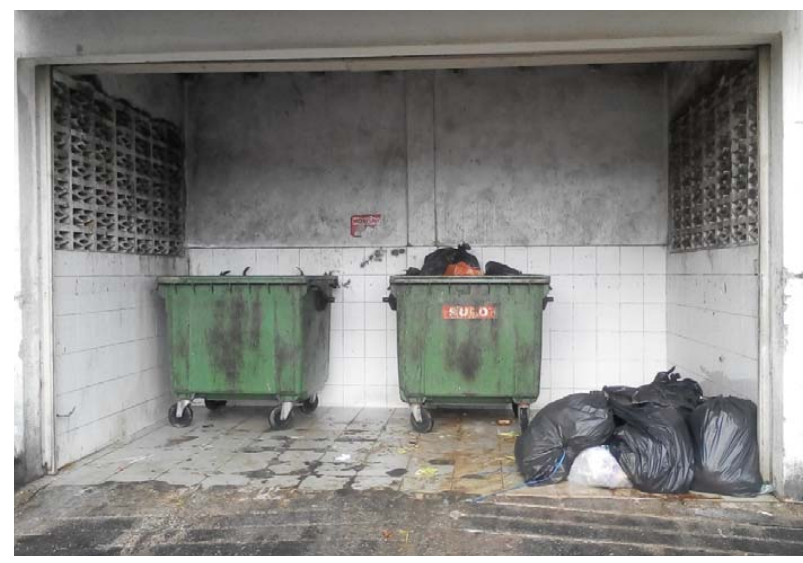

(A) Sampling site.

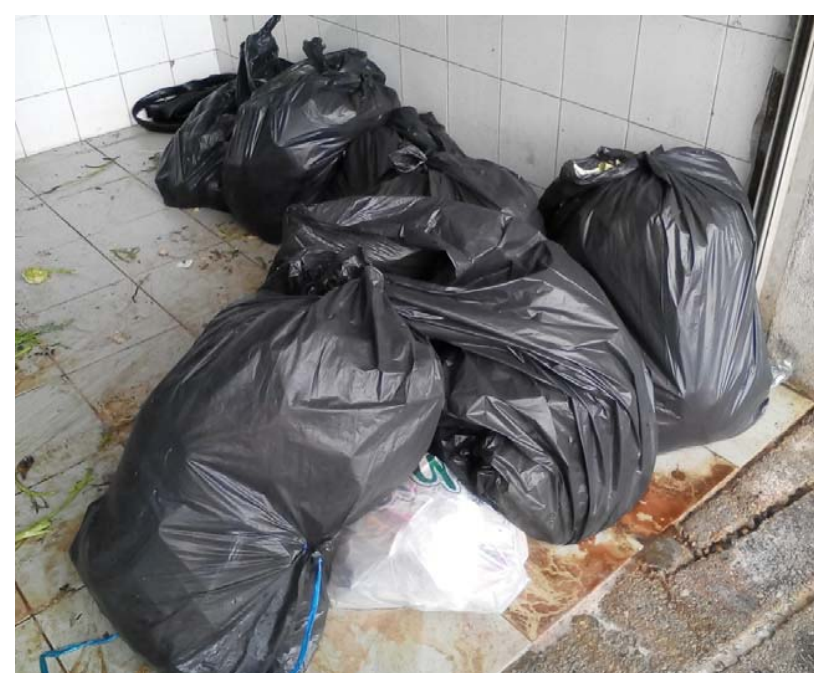

(B) Waste generated in a day.

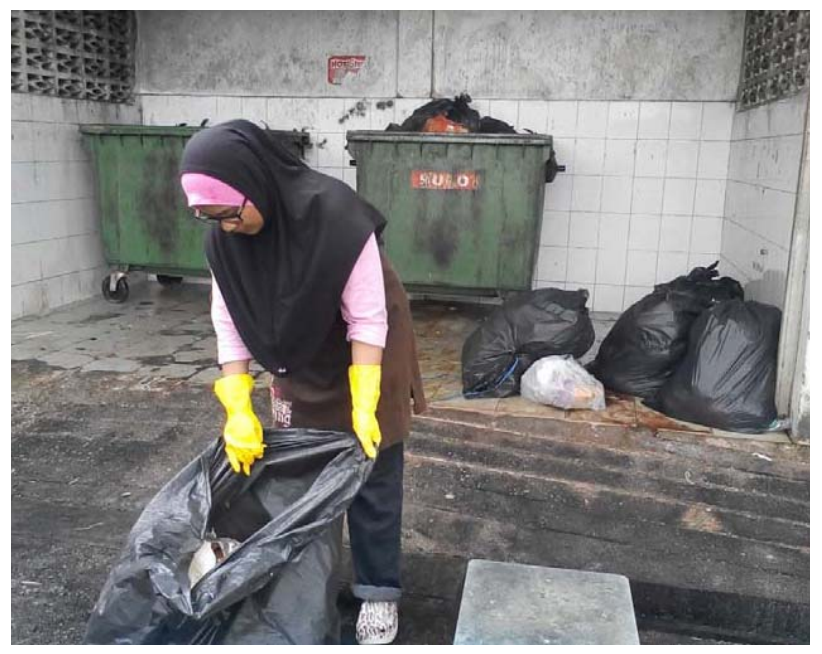

(C) Waste segregation.

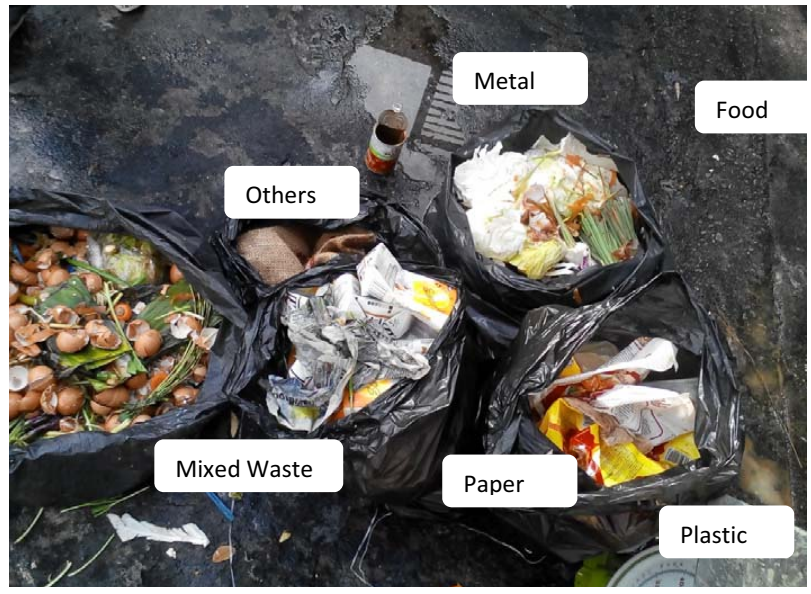

(D) Segregation by its composition based on Malaysian standards.

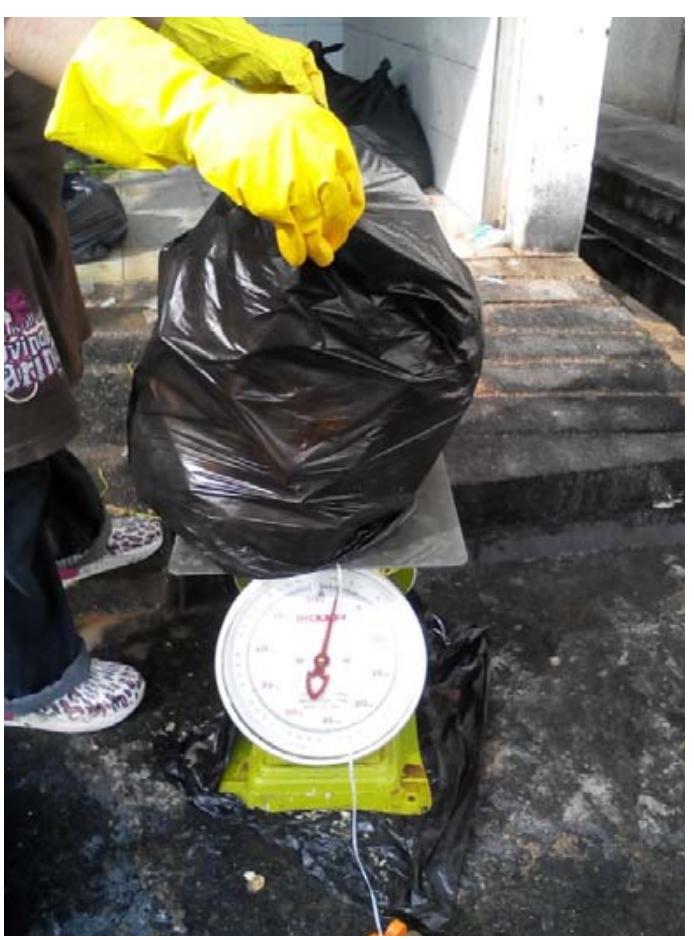

(E) Weighing process.

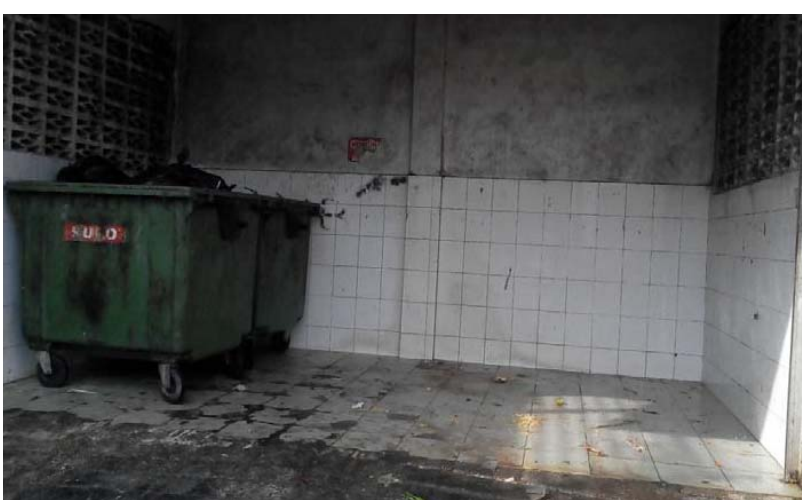

(F) Sampling process complete. 


\section{References}

1. GLOBAL ENVIRONMENT CENTRE. Solid waste in Malaysia. http://www.gecnet.info/index.cfm?\&menuid=83 (assessed on $3^{\text {rd }}$ October 2014), 2012.

2. MANAF L.A., SAMAH M.A.A., ZAKI N.I.M. Municipal solid waste management in Malaysia: Practices and challenges. Waste Manage. 2, 2902, 2009.

3. AGAMUTHU P., DENNIS V. Policy trends of extended producer responsibility in Malaysia. Journal of Waste Management \& Research. 29, (9), 945, 2011.

4. PPSPPA. Slide on an Overview of waste management in Malaysia, 2012.

5. LAWS OF MALAYSIA. Act 672 , Solid Waste and Public Cleansing Management Act. Government of Malaysia. http://www.kpkt.gov.my/kpkt_2013/akta/Act672y2007bi.pdf (assessed on $3^{\text {rd }}$ October 2014), 2007.

6. LAWS OF MALAYSIA. Act 127, Environmental Quality Act. Government of Malaysia. (assessed on $3^{\text {rd }}$ October 2014), 1974.

7. LAWS OF MALAYSIA. Act 655, Water Services Industry Act. Government of Malaysia. (assessed on $3^{\text {rd }}$ October 2014), 2006.

8. LAWS OF MALAYSIA. Act 304, Atomic Energy Licensing Act. Government of Malaysia. (assessed on $3^{\text {rd }}$ October 2014), 1984

9. NGOC U.N., SCHNITZER H. Sustainable Solutions for Solid Waste Management in Southeast Asian countries. Waste Manage. 29, 1982, 2009.

10. HAMATSCHEK E. Current practice of municipal solid waste management in Malaysia and the potential for wasteto-energy implementation. In ISWA World Congress 2010. Hamburg, 2010.

11. PERIATHAMBY A., HAMID F.S., KHIDZIR K. Evolution of solid waste management in Malaysia: Impacts and implications of the solid waste bill, 2007. Journal of Material Cycles and Waste Management. 11, 96, 2009.

12. TARMUDI Z., ABDULLAH M.L., TAP A.O.M. A review of municipal solid waste management in Malaysia. Jurnal Teknologi (Sains \& Kej.). 57, 41, 2012.
13. ALI A.O. Attitude of Malaysian on recycling of municipal solid waste: Case studies in the major towns of the east coast and north Malaysia. Degree of Doctor of Philosophy, Universiti Sains Malaysia, Pulau Pinang, 2008.

14. JPSPN. National Solid Waste Management Department, Ministry of Human Wellbeing, Housing and Local Government.

http://www.kpkt.gov.my/jpspn_en_2013/main.php?Content $=$ articles $\&$ ArticleID $=43 \& \mathrm{IID}=\left(\right.$ assessed on $3^{\text {rd }}$ October 2014), 2013.

15. HOORNWEG D., BHADA-TATA P. What a Waste: Solid Waste Management in Asia. The World Bank. Washington, D.C, 2012.

16. CHUA K.H., SAHID E.J.M., LEONG Y.P. Sustainable municipal solid waste management and GHG abatement in Malaysia. Journal of Green \& Energy Management. 4, (2), $1,2011$.

17. BUDHIARTA I., SIWAR C., BASRI H. Current status of municipal solid waste generation in Malaysia. International Journal on Advanced Science Engineering Information Technology. 2, (2), 16, 2012.

18. TIEW K.G., KRUPPA S., BASRI N.E.A., BASRI H. Municipal Solid waste composition study at Universiti Kebangsaan Malaysia Campus. Australian Journal of Basic and Applied Sciences. 4, (12), 6380, 2010.

19. YATIM S.R.M., ARSHAD M. A. Household solid waste characteristics and management in low cost apartment in Petaling Jaya, Selangor. Health and Environmental Journal. 1, (2), 58, 2010.

20. SAMAH M.A.A., MANAF L.A., AGAMUTHU P., SULAIMAN W.N.A. Real data composition of Municipal Solid Waste (MSW) generated in Balakong, Selangor, Malaysia. Life Science Journal. 10, (4), 1687, 2013.

21. SAMAH M.A.A., MANAF L.A., AHSAN A., SULAIMAN W.N.A., AGAMUTHU P., D'SILVA J.L. Household solid waste composition in Balakong City, Malaysia: trend and management. Pol. J. Environ. Stud. 22, (6), 1807, 2013.

22. KPKT. Pricelist on recycling materials. http://www.kpkt.gov. my/jpspn_2013/fileupload/hebahan/Kaedah-kitar-semula. jpg. (assessed on 15 November 2014), 2013. 